\title{
Effects of Temperatures on Symptom Expression by Sugarcane Infected with Different Strains of Mosaic Virus
}

\author{
Lii-Jang Liu ${ }^{1}$
}

\section{INTRODUCTION}

Mosaic probably is the most important sugarcane disease in Puerto Rico. This disease was responsible for severe losses to the sugar industry between 1921 and 1927 when the noble cane varieties Cristalina, B.H. 10 (12) and S.C. 12/4 were cultivated extensively. Variation in the type of reaction of various canes to strains $A$ and $D$ have been observed frequently in the greenhouse during summer months. It appeared that these changes in symptomatology might have been induced by high temperatures. It has been shown that temperature often modifies symptoms elicited by certain plant viruses. According to Best (2), ${ }^{2}$ tobacco mosaic virus incites formation of small, discrete necrotic lesions on Nicotiana glutinosa at low temperature $\left(10^{\circ} \mathrm{C}\right.$.). At $35^{\circ} \mathrm{C}$. or above there was no necrosis. Instead, chlorotic blotches were formed and the virus became systemic. In Puerto Rico, Bird, Tió, and Sánchez ( 8 ) observed great variation in the type and severity of symptoms incited by two strains of the cucumber mosaic virus on the plant species $M$ usa sapientum L., $M$. paradisiaca L., Commelina longicaulis Jacq., and Cucumis sativus L. kept at different temperatures $\left(65^{\circ}, 75^{\circ}\right.$, $85^{\circ}$, and $95^{\circ}$ F.) in climate chambers.

Although Summers (5) pioneered in the identification of strains of the mosaic virus in Louisiana, and Bruehl (4) identified the three mosaic strains A, B, and D in Puerto Rico using differential hosts C.P. 31-294, C.P. 29-291, Co. 281, and Louisiana Purple, neither specifically studied the effect of different temperatures on symptom expression by sugarcane infected with different strains of the mosaic virus. The present studies were undertaken in an effort to obtain such data. It was thought results of such studies might be valuable in differentiating the several strains of the virus.

\section{PROCEDURE AND RESULTS}

Plants of the sugarcane variety C.P. 31-294 were planted in flats at the rate of 40 per flat and inoculated with mosaic virus strain A and B separately. The inoculated flats were kept in the greenhouse until typical mosaic

1 Phytopathologist, Agricultural Experiment Station, Mayagüez Campus, University of Puerto Rico, Río Piedras, P.R.

2 Italic numbers in parentheses refer to Literature Cited, p. 131-2. 

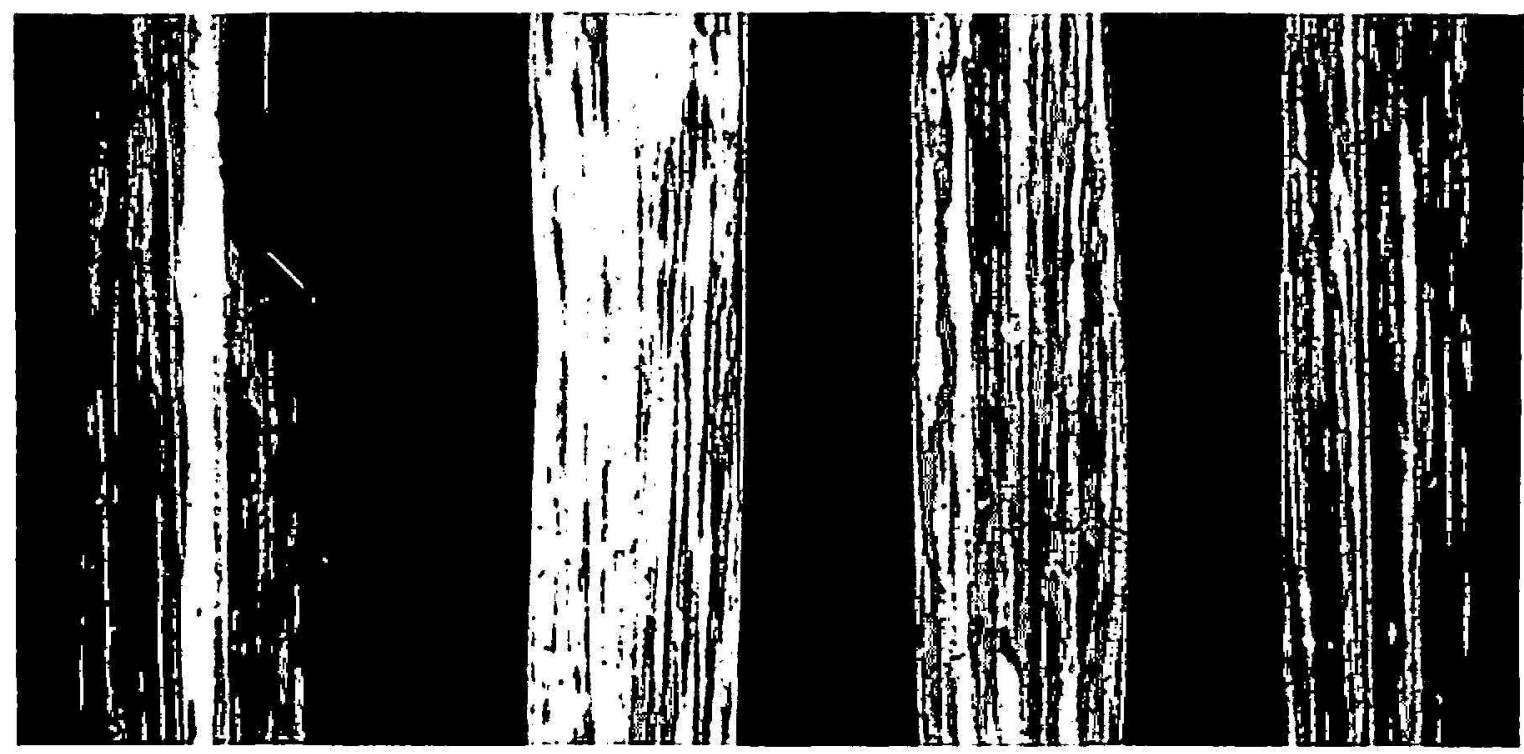

Fig. 1.-Effect of temperatures (from left to right $95^{\circ}, 85^{\circ}, 75^{\circ}$, and $65^{\circ} \mathrm{F}$.) on symptom expression of sugarcane variety C.P. 31-29.4 affected by mosaic virus strain B.

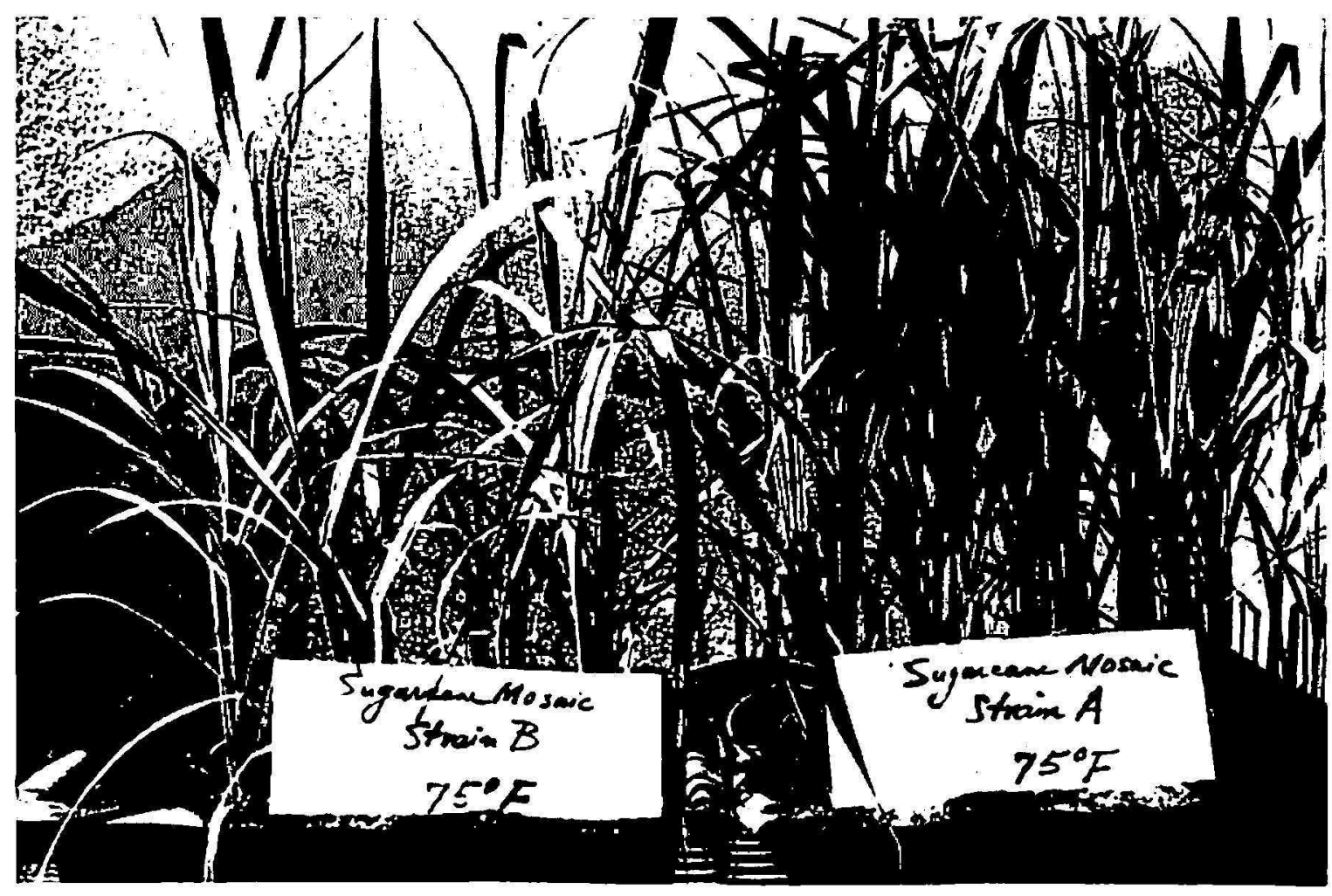

Fir. 2.- liffect of temperature $\left(75^{\circ}\right.$ F.) on growlh of sugarcane variety (C.P. 31-294 affected by mosaic virus strains $A$ and $B$. 
symptoms developed. They were subsequently divided into 4 groups according to temperature treatments $\left(65^{\circ}, 75^{\circ}, 85^{\circ}\right.$, and $95^{\circ} \mathrm{F}$.) and moved to the respective temperature chambers (each group consisting of 2 flats, one inoculated with mosaic virus strain $A$ and the other with strain $B$ ). At 14-day intervals the symptom pattern on all plants was observed and data recorded. The results indicated that canes affected by mosaic virus strain $\mathrm{A}$ and kept at $85^{\circ} \mathrm{F}$. were evidently more chlorotic than those kept either at $65^{\circ}$ or at $75^{\circ} \mathrm{F}$. Similarly, canes affected by mosaic virus strain B and kept at $85^{\circ} \mathrm{F}$. showed more necrosis than those kept either at $65^{\circ}$ or

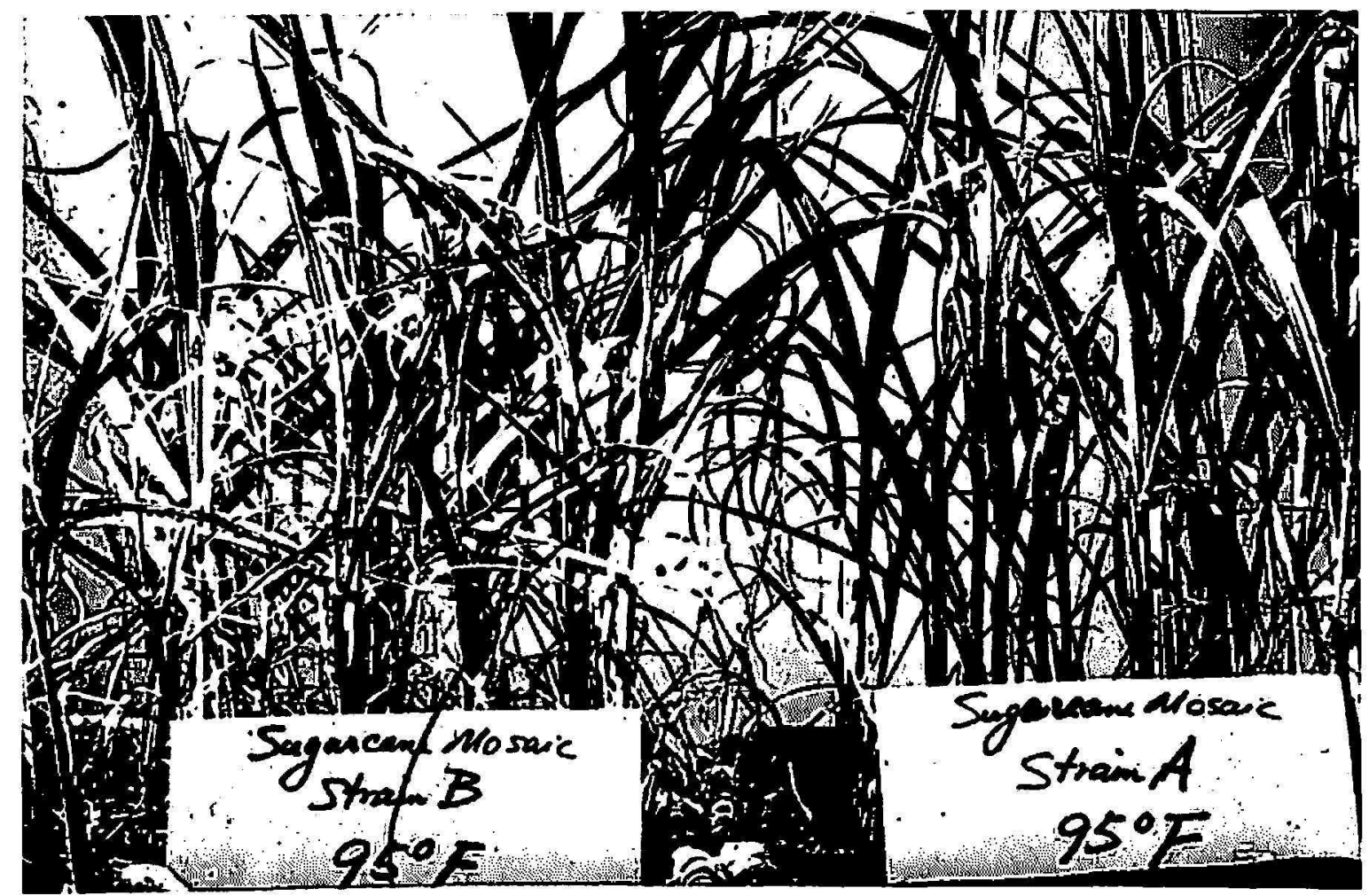

Frg. 3.-Effect of temperature $\left(95^{\circ}\right.$ F.) on growth of sugarcane variety C.P. 31-294 affected by mosaic virus strains $A$ and $B$.

at $75^{\circ} \mathrm{F}$. None of the canes developed necrosis when kept at the highest temperature $\left(95^{\circ} \mathrm{F}\right.$.) (fig. 1$)$.

At $75^{\circ} \mathrm{F}$., canes affected by mosaic virus strain $\mathrm{B}$ were more stunted than those affected by strain A (fig. 2). However, at the highest temperature $\left(95^{\circ} \mathrm{F}\right.$.), canes affected by both strain A and B grew equally well (fig. 3 ).

\section{DISCUSSION}

Presence or absence of necrosis on a selected differential host has bcen an important diagnostic character for differentiating strains $\mathrm{A}, \mathrm{F}$, and $\mathrm{H}$ from strains B, C, and D. Similarly, growth retardation was used by Summers, 
Brandes, and Rands (6) in 1948 as the principal character to differentiate strain $D$ from $E$ and strain $B$ from $G$.

After studying the effect of temperature on symptom expression and stability of strain D, Abbott (1) reported that temperature had no apparent effect on symptom expression or strain stability. The results of our studies clearly indicate there is a definite influence of temperature on symptom expression by sugar-canes affected by mosaic virus strains $A$ and $B$. Necrosis incited by mosaic virus strain $\mathrm{A}$ at $65^{\circ}, 75^{\circ}$, and $85^{\circ} \mathrm{F}$. did not occur at the highest temperature $95^{\circ} \mathrm{F}$. Similarly, growth retardation resulting from infection by strain $\mathrm{B}$ at low temperatures $\left(65^{\circ}\right.$ and $75^{\circ} \mathrm{F}$.) did not occur when the plants were kept at the highest temperature $\left(95^{\circ} \mathrm{F}\right.$.).

\section{SUMMARY}

A study was made to determine the effect of various temperatures $\left(65^{\circ}\right.$, $75^{\circ}, 85^{\circ}$, and $95^{\circ} \mathrm{F}$.) on symptom expression by sugarcane plants affected by mosaic virus strains $A$ and $B$ in climate chambers. Symptoms incited by both strains A and B on sugarcane differential host C.P. 31-294 were best observed at $85^{\circ} \mathrm{F}$. Necrosis produced by strain $\mathrm{A}$ at $65^{\circ}, 75^{\circ}$, and $85^{\circ} \mathrm{F}$. did not occur at $95^{\circ} \mathrm{F}$. Growth retardation resulting from infection by strain $\mathrm{B}$ at $65^{\circ}$ and $75^{\circ} \mathrm{F}$. was not observed at $95^{\circ} \mathrm{F}$.

\section{RESUMEN}

Se hizo un estudio para determinar el efecto de varias temperaturas $\left(65^{\circ}, 75^{\circ}, 85^{\circ}\right.$, y $95^{\circ} \mathrm{F}$.) en la expresión sintomática de plantas de caña de azúcar afectadas por las cepas A y B del virus del mosaico de la caña, cultivadas en cámaras climáticas. Los sintomas incitados por ambas cepas, A y B en el huésped diferencial C.P. 31-294 se manifestaron mejor a una temperatura de $85^{\circ} \mathrm{F}$. La necrosis producida por la cepa $\mathrm{A}$ a temperaturas de $65^{\circ}, 75^{\circ}$ y $85^{\circ} \mathrm{F}$. no ocurrió a los $95^{\circ} \mathrm{F}$. La condición de crecimiento retardado, como resultado de la infección de la cepa $\mathrm{B}$ a $\operatorname{los} 65^{\circ}$ y $75^{\circ} \mathrm{F}$., no se observó a los $95^{\circ} \mathrm{F}$.

\section{LITERATURE CITED}

1. Abbott, E. V., and Tippett, R. L., Strains of sugarcane mosaic virus, Tech. Bull. 1340, USDA, 1966.

2. Best, R. J., The effects of light and temperature on the development of primary lesions of the viruses of tomato spotted wilt and tobacco mosaic, Austral. J. Exp. Biol. Med. 14: 223-9, 1936.

3. Bird, J., Ti6, M. A., and Sánchez, J., Effect of various temperatures on different plant species (cucumber, plantain, and banana) affected by cucumber mosaic virus. Paper presented at the A.P.S. Caribbean Div. Mtg., Mayagüez, Puerto Rico, October 1968. 


\section{2}

JOURNAL OF AGRICULTURE OF UNIVERSITY OF PUERTO RICO

4. Bruehl, G. W., Strains of sugarcane mosaic in Puerto Rico, Plant Dis. Rptr., ARS, USDA 37: 479-81, 1953.

5. Summers, E. M., Strains of the sugarcane mosaic virus in Louisiana, Int. Soc. Sugarcane Technol. Proc. 6: 723-9, 1935.

6. Summers, E. M., Brandes, E. W., and Rands, R. D., Mosaic of sugarcane in the United States with special reference to strains of the virus, Tech. Bull. 955, USDA, 1948. 